\title{
THE STRATEGIES FOR BOOSTING EMPLOYEE MORALE IN AN ORGANISATION
}

\author{
Dr. C K GOMATHY, Ms. C.V.S.VASAVI, Mr.CH.HARSHAVARDHAN REDDY, Ms.A.SRIJA
}

Sri Chandrasekharendra Saraswathi Viswa Mahavidyalaya , Kanchipuram

\begin{abstract}
Morale is an Employee's attitude towards His or Her Job, Employer, and Colleagues. Employee Morale as the Psychological state with respect to satisfaction, confidence and resolve; The attitude of an individual or group of Employees, resulting in courage, devotion and discipline; Level of fulfillment one has with Intrinsic Work aspects, Such as Variety and Challenges, Feedback and Learning. Morale is essentially an in general attitude of an individual or group towards all aspects of work in a Organization. Morale even leads to effective work.
\end{abstract}

Keywords: Employees Attitude, Employee Behavior, Employee, Engagement, Employees Morale, Organization.

\section{I . INTRODUCTION}

The present universe of competitiveness each business needs his/her representative ought to claim possess compensation in which his/her work would be valued and helps them to have a place. Employee's dedication emerges from once Morale goes about as critical enthusiastic perspective of a man whose efficiency improvement is straightforwardly identified with in the workers. By testing their feelings, state of minds and viewpoints towards the Organization. Since Workers with positive attitude results in high efficiency regarding the principles and motive of an Organization.

Employees connecting with themselves in a negative confidence have a tendency to carry on and act contrarialy which hampers the working condition.

\section{MEANING OF MORALITY}

Morale may be defined as an intangible feeling that refers to how positive and supportive a group or individual feels towards the organization to which it belongs and how they share it with others.Such as trust,self-worth,purpose or pride in one's achievement and faith in an organizational success.

\section{CAUSES OF LOW MORALE OF EMPLOYEES IN A COMPANY}

Before we look at the ways to boost work morale,It's helpful to understand where low employee morale comes from.After all,"Prevention is better than cure."Now we will see the reasons for less morale in employees

*Lack of Growth

*Lack of Clarity and Communication

*Leadership Changes

*Leadership Problems 
*Issues in the Company Itself

\section{III.PROBLEM STATEMENT}

Between creating an enabling environment for the employees and handling out incentives to them is the list of measures needed to boost the spirits of the employees . Without this extra nudge,the situation is usually of the apathy and the lack of the will to put the extra efforts past the agreed one's that are in the job description.However the employees finds that is the extra efforts on the parts of the employers that the efforts make all differences So employee's device systems knows as reward systems which"addresses these four areas like compensation,benefits,recognition and appreciation".However not only for appreciation and recognition, the one who does not make to it's system equally compensated in order to help boost their morale in the job.The research problem at the heart of this study is to identify and discuss the numerous strategies employed by organisations for the purpose of boosting employee Morale in this case study.

\section{IV . ACTIVITIES TO IMPROVE MORALITY}

The morality in employee's plays an important role in development of a company.For improving that morality in employee's one can (else a company)can perform some activities.In that we can always say that a employee is always needs motivation for completing his job perfectly.The company must encourage the employees by appreciating their interest and efforts towards work and then another way to improve morality is organizing some events and games during the weekoff to make them enthusiastic,As all we know playing games makes people happy and excited,focused and many more.By these games they can even interact with all the other employees in the company . Even it develops morality and another way is recognizing their efforts towards work and providing them with gift vouchers and even giving them bonuses might even make them more trustworthy towards the company. By all these activities an employee can develop morality in himself and works effectively which makes the company's growth.

By performing all these activities not only improve morality and also another 15 most used ways to boost Employee Morale are:

\section{WAYS TO BOOST EMPLOYEE MORALE:}

1. Communicate Often.

2. Use the right tools.

3. Be transparent

4. Give Employee Recognition

5. Get employee Feedback

6 .Offer Employee Growth

7. Run a Calm, Healthy \& Organized company

8.Train Managers

9.Organize Team Building Activities

10.Provide Amazing Employee Incentives

11.Encourage Genuine Breaks

12.Promote Workplace Diversity

13.Let Go Of Workplace Bullies 


\section{Buy Some Green Office Plants}

15.Make a Designated Decompression Room for Breaks.

By performing all these activities, we can ensure that the Morale in Employees Will increase for sure to an extent by implementing all these activities in the company.

Now we will see what are the benefits after implementing all these and their benefits:

\section{BENEFITS OF EMPLOYEE MORALE}

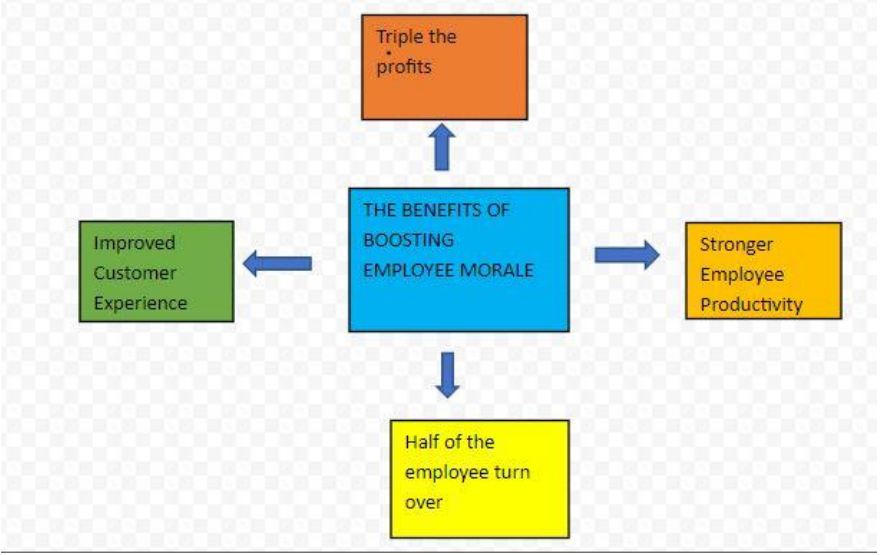

Fig 1: Benefits of Employee Morale

By Observing this fig 1 we can say that we have the best benefits by performing all above activities like the profits are increased to extent and leads to stronger employee productivity, turn over and many more.

As we all know all these reforms would be different during this pandemic situation as compared to physical it is virtual,By performing at least half of these activities how the morale increased benefits virtually we can see as follows

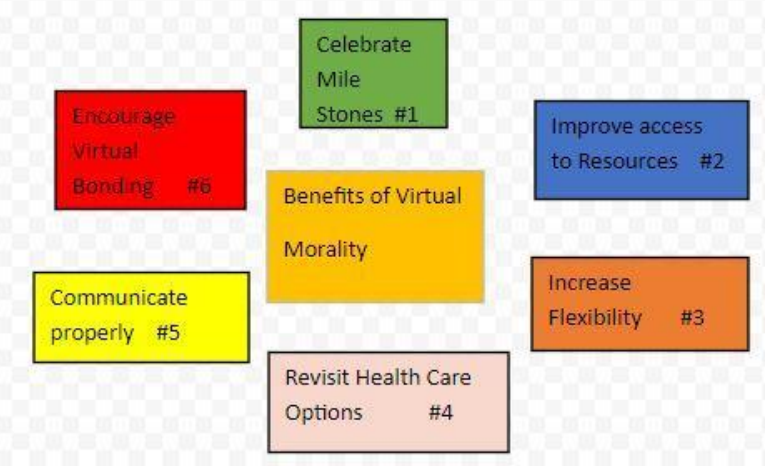

Fig 2 Benefits of Increased Morality Virtually

As we observe fig2 we can state that as employees feel tired work from home, At that time they will depress with working in a spotted place, So to make this revealed by performing some of the activities stated above we can make them work them effectively in virtual environment also,without loosing faith and hope in a company.We can also state that by doing all these activities we can see the benefits of morality even virtually and leads to success of an employee and company too.

\section{V.RESULTS}

By performing all these, We can expect very good results in a company. Even some of these methods are already in implementation and have succeeded.Even we can get accurate results from these activities, which are very much practically possible.

\section{CONCLUSION}

By all these we can conclude that Morality plays a key role in development of a company .If the employee is Physically and Mentally stable by performing all these activities ,he /she would be successful in developing morality which enhances the company development. 


\section{VII.REFERENCES}

1. Chandrasekar.K.(2011).Workplace environment and its impact on organizational performance in public sector organizations, International Journal of Enterprise Computing and Business Systems

1 (1).Finger J (2005). The Management Bible. New Holland Publishers Ltd.

2. Haddock P (2010). Importance of morale. Retrieved from http://www.ehow.com

3. Juliet,R, \& Bashiru,O.B.(2014). Fostering Employee Morale through Effective Remuneration Practices, European Journal of Business and Management. 6(16),

4. Mong,A .,Verma,N., \& Monga,O,P (2015), A Study of Job Satisfaction of Employees of ICICI bank in Himachal Pradesh, Human Resource Management Research 5(1):18-25

5.Dr.C.K.Gomathy,C K Hemalatha, Article: A Study On Employee Safety And Health Management International Research Journal of Engineering And Technology (Irjet)- Volume: 08 Issue: 04 | Apr 2021

6.Dr.C K Gomathy, Article: Supply chain-Impact of importance and Technology in Software Release Management, International Journal of Scientific Research in Computer Science Engineering and Information Technology ( IJSRCSEIT ) Volume 3 | Issue 6 | ISSN : 2456-3307, P.No:1-4, July-2018

7.Dr.C K Gomathy, Article: A Study on the Effect of Digital Literacy and information Management, IAETSD Journal For Advanced Research In Applied Sciences, Volume 7 Issue 3, P.No-51-57, ISSN NO: 2279-543X,Mar/2018

\section{AUTHOR'S PROFILE:-}

1.

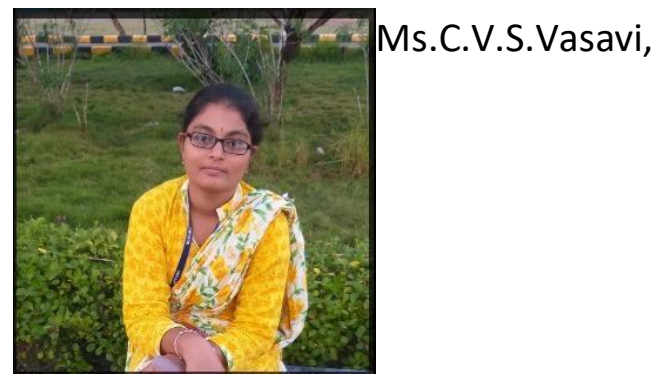

Student ,B.E. Computer Science and Engineering , Sri Chandrasekharendra Saraswathi Viswa Maha Vidhyalaya Enathur, Kanchipuram,India.

Her area of interest in Human Resources Development

2.

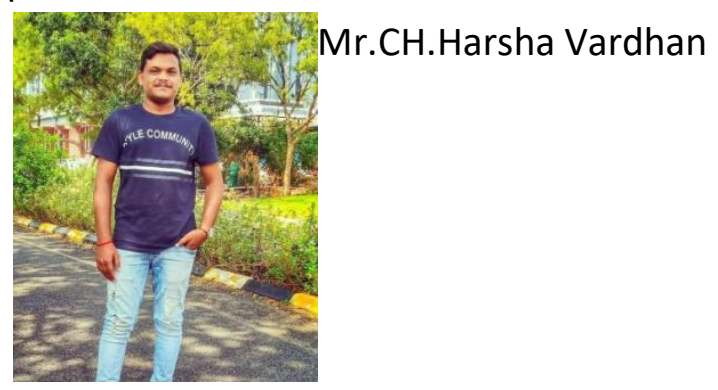

Reddy, Student , B.E. Computer Science and Engineering, Sri ChandraSekhrendra Saraswathi Viswa MahaVidyalaya Enathur ,Kanchipuram, India.

His area of interest in Human Resources Development.

3.

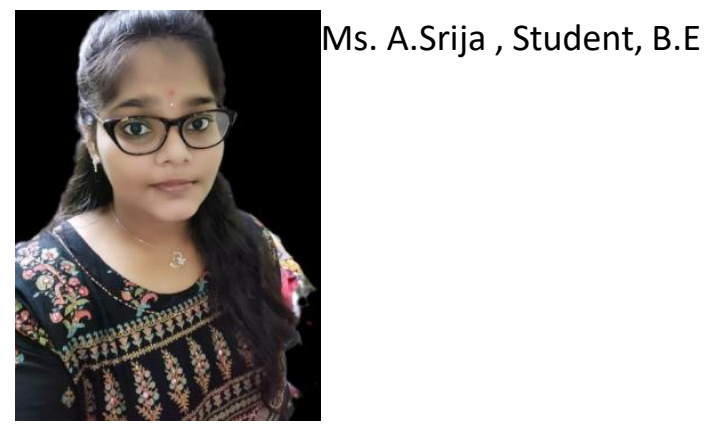

Computer Science and Engineering, Sri

Chandrasekharendra Saraswathi Viswa

MahaVidyalaya,Enathur, Kanchipuram, India. Her area of interest in Human Resources Development. 
4.

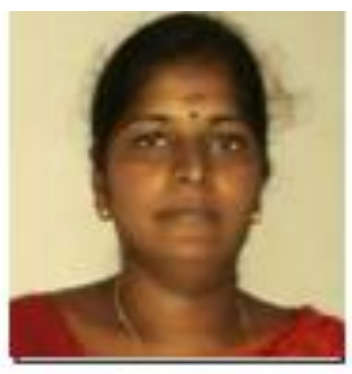

Dr.C.K.Gomathy

is Assistant Professor in Computer Science and

Engineering at Sri Chandrasekharendra Saraswathi

ViswaMahaVidyalaya,Enathur,Kanchipuram,India.

Her area of interest in Software Engineering,Web

Services,Knowledge Management,Human Resource

Management and IOT. 